\title{
FROM SEMENTOVSKIJ TO THE 20TH CENTURY. NOTES ON THE LUTSIS IN THE LATVIAN PRESS
}

\author{
Hannes Korjus \\ Latvian Association of Journalists, Rigga, LV \\ hannes@td.lv
}

\begin{abstract}
The Lutsis, a historically South Estonian-speaking language island community located near the town of Ludza in southeastern Latvia, have come increasingly into public awareness in Latvia over the last decade with the release of books on Lutsi history and language suitable for both professional and lay audiences as well as other new works relating to Lutsi folk culture. However, even before this recent burst of activity, the Lutsis have been mentioned in the Latvian and Estonian press and have also appeared in the field notes of researchers whose work was connected with the Lutsis. This article traces the descriptions of the Lutsis in a variety of sources from the first descriptions in the mid-19th century, through the interwar independence of Latvia, and as late as the 1970s when important expeditions by Latvian researchers documented the impressions of the last Lutsi speakers on the state of their language and culture.
\end{abstract}

Keywords: ethnic identity, endangered languages, minority languages, Finnic languages, South Estonian, Lutsi, Latgale, Ludza

DOI: https://doi.org/10.12697/jeful.2021.12.2.10

\section{Introduction}

The Lutsis, a historically South Estonian-speaking language island community located near the town of Ludza in southeastern Latvia, have come increasingly into public awareness in Latvia over the last decade with the release of books on Lutsi history (Korjuss 2017) and language (Balodis 2020) suitable for both academic and lay audiences as well as other new works relating to Lutsi folk culture including the 2019 album Lutsi Rahvalaulud / Ludzas igauņu dziesmas (Lutsi folk songs) released by the Cibla folklore group "Ilža". However, even before this recent burst of activity, the Lutsis have been mentioned in the Latvian and Estonian press and have also appeared in the field notes of researchers whose work was connected with the Lutsis. This article traces the 
descriptions of the Lutsis in a variety of sources from the first descriptions in the mid-19th century, through the interwar independence of Latvia, and as late as the 1970s when several important expeditions by Latvian researchers documented the impressions of the last Lutsi speakers on the state of their language and culture. This article also quotes extensively from original sources in translation providing a first-hand view of the developing understanding of the Lutsis by themselves as well as others.

Section 2 of the article details the earliest mentions of the Lutsis by outsiders; section 3 focuses on descriptions of the two earliest expeditions to the Lutsis by Oskar Kallas (in 1893) and Heikki Ojansuu (in 1911) as well as Lutsi reactions to them; section 4 describes the interactions of Paulopriit Voolaine - one of the most important 20th century researchers of the Lutsis - and his efforts to open Estonian schools in the Lutsi region as well as attitudes towards these efforts from Latvians and the Latvian government; section 5 discusses the work of Latvian composer Emilis Melngailis with Lutsi folk singers and the recognition they received in Latvia during the 1930s as well as Melngailis's efforts to determine whether Lutsi and Livonian were perhaps the same language; section 6 given an overview of the Latvian folklore research expeditions to the Lutsi area in the 1970s and describes Lutsi memories and stories of their origin as well as attitudes towards their language and folk culture at a time when the majority of the Lutsi community had already assimilated linguistically into surrounding language groups.

\section{First mentions}

In 1872, the Vitebsk Statistics Committee published Aleksandr Sementovskij's (Александр Сементовский, 1821-1893) study Etnografičeskij obzor Vitebskoj gubernii (An Ethnographic Overview of Vitebsk Governorate). In its introduction, Sementovskij wrote: "As a science, ethnography has never attracted the attention of scientists and educated people in general, as much as in the second half of this century when the national question has also become part of questions of state policy. Never in the past have we, Russians, given so much attention to the nations, which inhabit our homeland spanning half the globe, as we have in the last decade. The need for ethnographic studies, especially 
in our northwestern periphery, could be fully felt only after the Polish uprising from 1863 to 1864 (Polish: powstanie styczniowe)."

Gustaw baron Manteuffel-Szoege (1832-1916) wrote the following in his book Inflanty Polskie (Polish Livonia) (Manteifels 2020: 67-68):

"Energetic in their character and extremely dirty. Numbering approximately 3000 , precisely 2886 persons from both genders. They live among the Latvians and Russians on the state properties in Mihalova and Janovole as well as next to Pilda manor in Ludza County ${ }^{1} 85$ miles away from their nearest countrymen. They have preserved their language and customs, but have given up their black clothing, which they had worn in the past. Some of them are Roman Catholic, but in the 1840 s, a portion of them were forced to convert from Greek Uniates to Russia's ruling church. A notable article by the esteemed researcher of this nation, Dr. M. Veske ${ }^{2}(1843-1890),{ }^{3}$ was recently (1877) published in Tartu in the yearbook of the Learned Estonian Society. It claims that the aforementioned Estonians of Polish Livonia and Pilda manor, which currently belongs to St. Petersburg Professor Theodor Stein, came from Swedish lands (Rootsi maalt) or "the Swedish king's land" (Rootsi kuninga maalt), which is evidenced by the traditions they have preserved. They left their homeland when the current Livonian Governorate belonged to Sweden. Dr. Veske had heard from an Estonian from Pilda manor that his great-grandfather had arrived from the land of Rīga (Riia maalt) with his countrymen, whose descendants now live in Polish Livonia. The man was about forty years old and his greatgrandfather had been a small boy at the time. The Estonian language of Polish Livonia, according to Dr. Veske, undoubtedly belongs to the Võro dialect (Werroscher Dialect). The differences are insignificant, they had to have arisen due to an ancient split from the core of the nation. Dr. Veske promises to acquaint us with the features of their language at a later time."

The Lutsis had come to Mihkel Veske's attention in 1877. During the construction of the Baltic railway, he had met a couple of Lutsi men ("Maajumala poig" 1943). Uldis Balodis has noted that information

1 Latvian: aprinkis

2 Mihkel Veske (28 January 1843-16 May 1890) was an Estonian theologian and linguist.

3 See Dr. M. Weske "Über die Witebskischen Esten" in the publication Verhandlungen der gelehrten Estnischen Gesellschaft zu Dorpat. Dorpat, 1877, Vol. 8. Ntbk. 4, pgs. 29-33. 
about the Estonians of Ludza appears in Mihkel Veske's study Bericht über die Ergebnisse einer Reise durch das Estenland im Sommer 1875 (Report on the results of the Summer 1875 journey through Estonia). Veske describes meeting two Pilda Estonian labourers (Josef Antonof and his relative) in Estonia. The labourers told Veske - just as other Lutsis would tell other researchers in the future - that their ancestors came from "the land of Rìga", "Sweden", "the Swedish king's land" (Balodis 2020: 94).

\section{First researchers and Lutsi attitudes}

In 1892, Oskar Kallas (1868-1946) read an article in Postimees by St. Petersburg correspondent Karl August Leopas (1854-1940) ${ }^{4}$ about the Catholic Estonians of Latgale (Leopas had learned about them from a Catholic seminary student from Latgale who was studying in St. Petersburg at the time). This article by K. Leopas - he was the owner of a St. Petersburg book and note store - was published on 10 September 1892 on the front page of Postimees right under the headline and signed with the initials K.L. Correspondent K.L. reported that on a train from Tallinn to St. Petersburg, a Polish seminary student had told him that there were many Catholic Estonians living in the Vitebsk Governorate.

This coincidence created sudden and particular interest. Oskar Kallas provided the first extensive information on the Lutsis. Kallas travelled widely across the Ludza area in 1893 and recorded information about the Estonians living there and their language. Kallas published separate reports on his journey in Estonian and German. The most important of these for the Lutsis was his 1894 monograph Lutsi maarahvas (Ludza Estonians, lit. Ludza country folk). ${ }^{5}$ In 1900, Kallas published collections of Lutsi stories in Estonian and German.

Following Oskar Kallas's 1893 expedition to Ludza County in Vitebsk Governorate, to visit the Estonians living near Ludza who spoke - more or less - their own unique dialect, news about the Lutsis also appeared in books as a well as periodicals published in the Vitebsk and Livonian Governorates.

4 K. Leopas Eesti rahva unustatud suguharust. Postimees, 10.09.1892, No. 202.

5 See Uldis Balodis "Ludzīlazest: Who are the Lutsis?"

$\mathrm{http} / / /$ lutsimaa.lv/Lutsimaa_Land_of_the_Ludza_Estonians/Who_are_the_Lutsis.html 
Latgalian writer, politician, and culture worker Francis Kemps (1876-1952) mentioned the Lutsis in his book Latgalieši (The Latgalians):

"In Pilda and Nerza parishes ${ }^{6}$ in Ludza County, Estonians have lived in about six villages since ancient times, and in Rēzekne County. When and how these foreigners came here cannot be clearly determined. They also do not have anything to tell about their arrival. According to the old people in the villages, during serfdom, manor lords had often traded people for hunting dogs, and every one of the current Estonian or Lithuanian villages stems from a particular family which had once been traded in Lithuania or Estonia for dogs.” (Kemps 1910: 46-47)

Francis Kemps knew of the Lutsis, but in 1925, when Ernests Blese ${ }^{7}$ (1892-1964) wrote about the inhabitants of Latgale, the Estonians no longer merited a mention. The Estonians of Latgale were, apparently, a numerically small enough group to remain unnoticed:

(a) "Everyone knows that the ethnic composition of Latgale is very diverse. In addition to the main ethnicity - the Latvians, whose percentage relative to other ethnicities is lower in Latgale than elsewhere in Latvia and in Latvia in general, we also encounter a large number of Russian, Belarusians, Poles, Lithuanians, and Jews in Latgale." (Blese 1925: 357)

(b) "All of these ethnicities have not been in Latgale equally long. Historically, the oldest of these are the Russians, Belarusians, and partially also the Lithuanians, the newest arrivals in Latgale are the Poles and Jews. Each of these ethnicities, with the exception of the Jews, has their own native language." (Blese 1925: 358)

Oskar Kallas (1894) wrote that though at first the Lutsis were rather hostile towards him (i.e., Kallas - author's note), in time they would treat him almost like their king. At first the Lutsis thought that Kallas was spreading cholera among them, there were even some who claimed that Kallas wanted to make trouble for the Lutsis. The local people detained

6 Latvian: pagasts.

7 Ernests Blese (1892-1964). Latvian linguist, University of Latvia philology professor (1928-1944), Germersheim University professor (1947-1964). Researcher of Latvian person names and family names. 
Kallas and took him to their parish hall, where Kallas was released but the Lutsis received a harsh punishment. In time, people began to view Kallas as "the king's son", "a seer", "the czar's emissary". When 18 years later (in 1911), Professor Heikki Ojansuu of Finland (University of Helsinki dean) arrived in Latvia, that is near Ilzene, excesses similar to Kallas's experiences were repeated. Some of the residents of Ilzene (Ilzene parish is located in the southwestern part of Alūksne municipality) were stirred up by rumours that he (i.e., Heikki Ojansuu) was a false prophet, the Antichrist, that the end of the world was nigh. But later all of this died down ("No Ilzenes" 1911).

In that same summer of 1911, Finnish researcher Dr. Heikki Ojansuu and stud. phil. Ed. Gulbis of Tartu also came to the area near Pilda in Latgale. Their expedition attracted the attention of the newspaper Dzimtenes Vēstnesis:

"Rare guests have come to our dark end, about which little is ever heard in the newspapers: University of Helsinki dean Dr. Ojansuu and stud. phil. Ed. Gulbis of Tartu. Their intent is to study the relationships among local languages (Estonian, Latvian, Russian) and how they have changed. It should be noted that Estonian colonists were settled here 200 years ago. Living among the local Latgalians and being in close contact with the Russians, for the most part they have already forgotten their mother tongue and now are considered to be Latvians. The people are superstitious, uneducated, and ignorant, and therefore they view the aforementioned strangers with great suspicion and do not understand their scientific intentions. It would be welcome if even the local clergy, which holds great sway among the people, instructed them that there is no basis for mistrust here. R." ("Pilda" 1911)

The local [Catholic] clergy received praise in a different article authored by Dr. Heikki Ojansuu's travelling companion: ${ }^{8}$

"They are helpful, kind, heartfelt - characteristics that immediately bind a stranger's heart to them. At first we lived for about a week with Pilda priest Gedvillo. ${ }^{9}$ Kind, genuine, humble in his nature, he was helpful to us more than just once. I still remember the first day at the priest's

8 This travelling companion was apparently Ed. Gulbis, because in the newspaper Dzimtenes Vēstnesis (04.07.1911) an article was published with the same title "Kur Latgale beidzas" (Ceḷojuma pēczīmes)" - author: Ed. Gulbis.

9 Julijans Gedvillo (1864-1929). 
home. Sunday morning, approximately eight o'clock...We drank our tea and then also walked up the chapel hill. The small church was overflowing mostly with women who had dropped to their knees and were reciting prayers. It was my first time seeing a Catholic church service and I can't deny that I wasn't a little surprised by all of this strange singing, music...loud prayers. But when I heard the sound of my beloved Latvian language.... ancient melodies, these people once again felt close and with a strange sense of self-respect, it seemed to me as if noble Rome herself had learned to speak in the Latvian tongue. And when the long prayers had ended and the bell in the tower sounded a few closing words, then the people scattered with their small hymnals in hand. And whoever has a need, they simply go up to their priest at the same chapel hill and tell him about their need. The priest kindly listens to all of them, sometimes joking or telling them about something from the newspaper. Every morning around 10 o'clock, the priest goes to the chapel and holds mass, which lasts for a couple of hours. He is a true servant of the Lord. And he must always be prepared and worthy of performing his exalted duty. But what is his salary? And still what energy in performing his duties and in his relationship with his congregation..." (“Kur Latgale beidzas" 1911: 586-588)

This aforementioned travelling companion also wrote:

"During the summer all the men most able to work travel to Russia to earn money, as they say "burlakos". I asked why they do not go to the Baltic [governorates] where work would not be as hard and the pay is no worse; they respond that they did not know about this... They are surprised when they are told that there is a Vidzeme and Kurzeme where Latvians also live, a great many Latvians; they think that they alone compose the entire Latvian nation and that their language is the real one. In "Škirpāni”" there are about 20 heads of homesteads, each of whom has been allotted about 1 or 2 pūrvietas ${ }^{10}$ of land. The land is cut into narrow strips, so narrow that in places a ploughman and his horse can barely turn around. Due to the paltriness of their land, the men leave every spring to earn money; as soon as the snow begins to vanish, agents recruit them for all manner of work, like canal digging, road building, and so on. One party was even sent to the Amur region. Only the disabled, women, and children remain at home. Dz.V." ("Kur Latgale beidzas" 1911: 586-588).

10 A "pūrvieta" is a traditional Latvian areal unit of measure equalling approximately one-third of a hectare. 
In 1913, the Estonians of the Ludza area were mentioned in passing: "In terms of its ethnic diversity, Latgale is strongly reminiscent of Austro-Hungary. In addition, there are Estonian and Jewish peasants living in a few villages in Pilda and Michalewa parishes. As in AustroHungary, also here no nation has achieved particular dominance in its position." (“Tautību stāvoklis" 1913).

\title{
4. Paulopriit Voolaine and Estonian schools
}

Paulopriit Voolaine, who had become an admirer of Kallas and Ojansuu, first visited the Lutsis in the summer of 1921 on scholarship from the Academic Mother Tongue Society (Akadeemiline Emakeele Selts). Researcher Indrek Jääts describes Voolaine's work and role as follows:

\begin{abstract}
"Voolaine utilised the promotion of the Lutsi cause, the personality of Oskar Kallas and memory of his 1893 field work. After the months and years that he lived among the Lutsis, Voolaine undoubtedly came to know the Lutsis even better than Kallas himself. With his stories about the Lutsis he was the main "importer" of these topics in the Estonian press. At one point he even earned the title "King of the Lutsis" on the humour page "Sädemed" in the newspaper Postimees (Postimees, No. 111, 26.04.1936). Kallas, who Voolaine, apparently, greatly admired, was in terms of his position in academia and society, of course, a first-order star compared to Voolaine. So, Voolaine mentioned Oskar Kallas's prestigious first and last names in many of his articles in the belief that it would work to the advantage of the cause. Voolaine waved Kallas's last name like a flag that could inspire both the Lutsis as well as Estonian society." (Jääts 2014: 28)
\end{abstract}

Voolaine's own attitudes towards his work and the reasons and importance for preserving Lutsi language, culture, and identity can be seen in the following two excerpts from articles he authored in the 1920s published in Postimees and Üliõpilasleht, respectively:

"Waves of foreign nations have not yet washed them out to sea, they are a forgotten islet in a sad Latgale backwater beyond the city of Ludza. Foreign currents of water have not yet caught these Estonian countrymen in their eddies, leaving behind only the hush of a monotonous sea of nations. I had planned to go to the funeral of the last Lutsi and ring 
the bells for the dear departed, those brothers and sisters who were banished in bygone times from Terra Mariana; but to my amazement, I found 2 islands where I could inhale the air of Old Estonia where the living language of South Estonia echoed from the mouths of the old end even some of the young." (Voolaine 1921)

"Nothing can be permitted to turn us into pessimists with respect to saving our nation. A patriot of our small nation must always hold the gospel of our nation in his hands, with which he must find his path to the islands of our countrymen, which are drowning in the hostile and destructive raging of foreign waters." (Voolaine 1926)

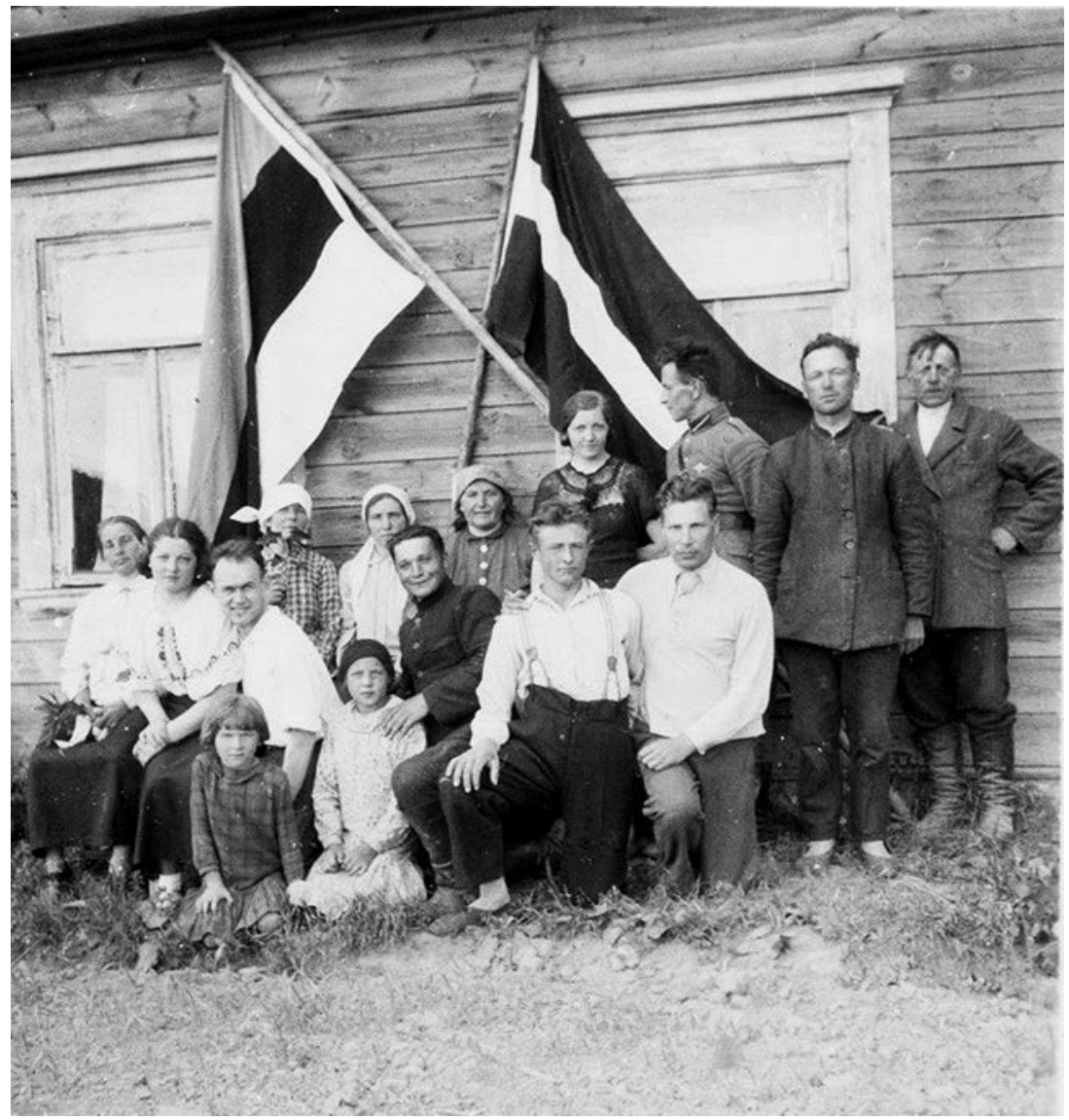

Figure 1. Paulopriit Voolaine (on the right in a white shirt) with Lutsis in Greči village. (Photo: August Sang, 1936, ERM Fk 756:12). 
Education became one of Voolaine's main directions for strengthening Lutsi identity not only in the present but also reinvigorating it for the future. He supported the opening of Estonian schools in the Lutsi region as well as helping Lutsi young people study in Estonia. These activities would ultimately lead to Voolaine's expulsion from Latvia with him only being able to return during the Soviet years. From an overview of his work in the 1920s and 1930s, which Voolaine compiled many decades later in December 1963, we read the following:

"In 1926, from January until July, I lived in Pilda parish in Škirpāni village (Kirbani küla) and Lielie Tjapši village (Tsäpsi küla). Thanks to the support of the Riga Estonian Education and Aid Society, ${ }_{11}^{11}$ began to work with matters connected to the education of the Estonian diaspora." (Voolaine 1963)

On 14 December 1930, Voolaine noted that the Pilda parish council had met on 17.12.1930 to discuss the possible opening of a Lutsi school and that there already existed a list of 50 children of Lutsi descent whose parents wanted an Estonian school to be opened in Lielie Tjapši. The Nirza parish Estonians had the same sort of story. So, the Lutsis waited for a response from Estonian teachers who spoke Latvian and Russian ("Lutsi eestlased" 1930). However, in 1932, the attitude was already completely different. This can also be seen in Voolaine's piece in Postimees: "Pressure by Latvia on minority nations. What will the new direction mean for Estonian schools?"(Voolaine 1932)

Voolaine's activities did not go unnoticed by the press in Latgale, nor by Latvian government institutions. In 1932, the newspaper Latgales zingas published an article about Ludza County schools; its author was teacher Jūlijs Ozols:

"Estonian parallel classes have been set up at the Filandmuiža 4-year primary school. So a new minority! Several Estonian families settled in Pilda parish in the past. The oldest generation still speaks Estonian, but the youngest one doesn't. Last year an Estonian student ${ }^{12}$ arrived in Pilda parish who has registered practically half the parish as Estonians. Later, many of those who had been registered sensed this gentleman's

11 Estonian: Riia Eesti Hariduse ja Abiandmise Selts.

12 The student mentioned in this quote may have been Paulopriit Voolaine. 
true intent and did all they could to get rid of the Estonian ethnicity imposed upon them. According to local opinion, the Estonian parallel classes, as well as the private Polish primary school, have only been opened in order to assimilate Latvian children." (Ozols 1932) ${ }^{13}$

Ozols was not the only one who was fairly critical towards Estonian classes in Ludza County. Here is another example: "Estonian parallel classes have been opened at the Pilda parish school, though no one in the younger generation speaks Estonian - only because in the past a few Estonian families immigrated here." (Ludzeneeks 1932).

According to the data from the Republic of Latvia Central Political Administration (Galvenā politiskā pārvalde) card file, Voolaine (Latgalian: Povuls Volainis) was one of the main inspirers of Lutsi descendant youth and driving forces urging them to study in Estonia (Štšerbinskis 2007: 146). While he was collecting ethnographic and linguistic materials in Ludza County, he "confirmed to many local residents in Nirza and Pilda parishes, that their ancestors had been Estonians and therefore they should send their children to study at schools in Estonia, because children arriving from Latvia do not have to pay anything for their studies. In 1936, he and Estonian Education Union consultant Neeme Ruus ${ }^{14}$ recruited many boys from the aforementioned parishes to go study in Estonia. In 1939 (Latvian State Historical Archive, Central Political Administration card file, Volainis P.), Voolaine was forbidden entry to the Republic of Latvia (Štšerbinskis 2007: 145-146).

In 1937, the researcher of Livonian folklore Oskar Loorits (19001961) was expelled from Latvia (Kursite 2008), the same also happened to Voolaine (reported in Postimees in January 1938) (Jääts 2013). For comparison, in 1938, the Central Political Administration (CPA) of the Latvian Ministry of Interior, counted the number of Catholic priests of Lithuanian descent in the employ of Eduards Stukelis, the Counsellor of the Roman Catholic Archdiocese of Riga. In the opinion of the CPA,

13 Note: The identical article was also published in the magazine Audzinātājs (see Jūlijs Ozols Audzinātājs, No.1., 1932, pg. 23) Instead of "an Estonian student" it says "a Tartu student".

14 Neeme Ruus (1911-1942). In 1940, he was Minister of Welfare in the Estonian puppet government led by Johannes Vares-Barbarus, and from the end of July 1940, he was the Propaganda Secretary of the Estonian Communist Party. He stayed in Estonia to work underground, but was apprehended by the Germans and shot. 
because of Stukelis, Lithuanian clergy had been "placed in politically important congregations along the border where the Lithuanians need it". The CPA felt that the aforementioned priests were promoting the Lithuanianisation of Latvians. Stanislavs Kurḷandskis, who directed Lithuanian community life in Latgale, was also expelled from Latvia (Jēkabsons 2013: 109-110).

\section{Emilis Melngailis and Lutsi folk music heritage}

During Latvia's first independence period, the Lutsis were considered to be Setos, ${ }^{15}$ Finns, Livonians. In 1929, the magazine Mākslas un senatnes mēnešraksts Latvijas Saule (The Art and Antiquity Monthly "Sun of Latvia"; No. 85-86, 1929) published the following: "Searching for Livonians. The Folklore Archive has asked composer E. Melngailis to find traces of the ancient Livonians in Latgale as part of his folklore studies ${ }^{16}$ Nerza parish (Br.Z) pg. 952."

Composer Emilis Melngailis conducted an "experiment" by bringing along a Livonian, Didrikis Volganskis (1884-1968), with him from the Livonian Coast. Melngailis wrote:

"I really wanted to see if a Courlander from Cape Kolka could speak with the Livonians who still can be found in 7 places near Lejasciems, also in a few places near Ludza. The Cape Kolka fisherman type I brought along, Mr. Volganskis, truly stood out as dark-skinned among the light-toned Livonians. He also could not converse at all with the Greči village Livonians (in Nierza, near Ludza). He says 1, 2: iǩs, kaǩs, they say: $\bar{u} t s, k \bar{a} t s . "$ (Melngailis 1934: 112)

15 Cand. hist. A. Lazdina Ekskursants No.14 01.10.1935, pg. 306: “...it is interesting to note that Setos also live in Pilda and Nirza parishes in Ludza County who came here from their homeland. These Latgalian Setos are almost completely assimilated into the Latvians. It is unusual that this little nation has managed to maintain its unique characteristics [living] among the Russians including their brightly-coloured folk costumes, which must be considered the most beautiful and unique in all of Estonia." This quote gives an example of the view in Latvia during that time that the Lutsis are Setos.

16 Emilis Melngailis "Līvu pēdas Latgalē" (speech). Latvijas Kareivis, 23.03.1933. At the opening of National Education Week in Daugavpils. 


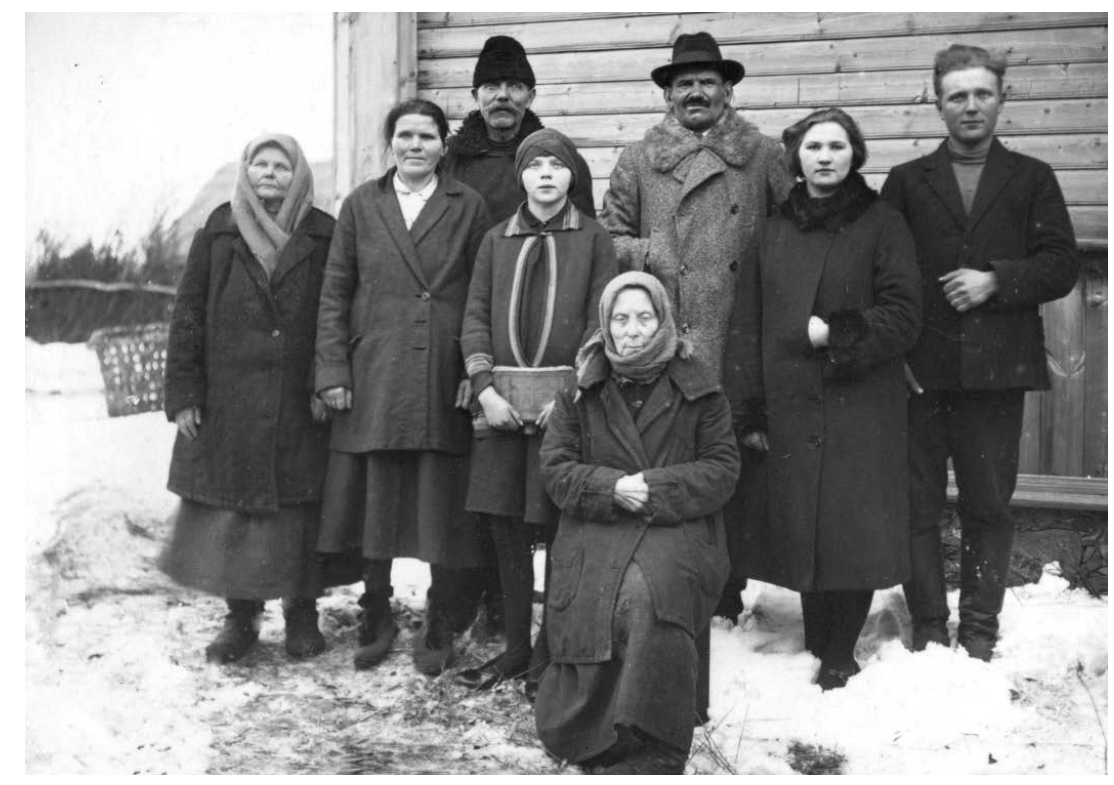

Figure 2. Rozālija Buḷa, 85 years old (front middle), Didriķis Volganskis (in a black hat behind Rozālija), Petruḷa Buḷa (last on left) in Greči village. (Photo: Emilis Melngailis, 1930, UL ILFA Archives of Latvian Folklore, image No. LFK $1045,57 \mathrm{c}) .{ }^{17}$

During the interwar years, the Lutsis had cause to feel proud of their countrywoman, singer and folklore research informant Petrula Buḷa from Greči village in Nirza parish. In news reports at the time we read of her being awarded the Silver Medal of Honour of the Order of Three Stars ("Galvas pilsētā" 1932). Emilis Melngailis also notes Petruḷa Bula's knowledge of Lutsi (which he calls Livonian) and mentions her among other figures he considered cultural luminaries at this time:

"That the storied castle of light, which is to be lifted up, can be found in folklore was already sensed by Krišjānis Valdemārs with his prescient mind. With a critical eye he separated the duties of his rival between those that are urgent and others that can be delayed. Without a lot of loud fuss, revolts, or hatreds, he urged the youth to collect folklore, organised Brīvzemnieks' trips, determined that Krišjānis Barons should undertake the task of collecting dainas. Next, Matīss Siliņš, the founder

17 http://garamantas.lv/en/illustration/377677/Greci-parish-near-Nierza. 
of that storehouse of ancient objects - the Latvian Museum - should be immediately named. What would the song festival be without costume displays, without ancient attire? Here is a photograph in which a noble group of singers is seated, but Matīss Siliņš, who is one of the few who has a deeper understanding of our antiquity, is standing behind them. That kokle player in the middle is the late Suiti master Henkis from whom I have written down both songs and dances. Seated to his left is Meklenburgu Dārta, who has given me the best melodies from central Korsa. Visible next to her is Buḷu Petruḷa from Greči village in N̦ierza, close to Ludza, who still knows the Livonian language. On the other side behind Heņkis you can see Uksilu Marinka with her goddaughter Piparu Margieta. Both of whom on their trip from Palanga to Rīga saw the railroad for the first time. On the end is Ulmanu Late from the same area in Kuldīga as Meklenburgu Dārta. They also still sing in Livonian in Ilzene near Lejasciems. Do not think that Courlandic is the same as Livonian. Where a Livonian says - ūts, kāts (= one, two), a Courlander says $i k \check{s}, k a k \check{s}$. The relationship is distant.” (Melngailis 1938: 24)

According to the information available in the Archives of Latvian Folklore (Latviešu folkloras krātuve), Melngailis used the song "Padzīdomi mes, mōsenis" sung by Petruḷa Buḷa, by including it in the beginning of his arrangement "Gaismen,a ausa". But Valdis Klētnieks also wrote about the kalado-song that Melngailis recorded, which Rozalija Buḷa and Petruḷa Buḷa had sung for him in 1930:

Ku-ze-ke-ne ku-ze-ke-ne, kalado, kalado

(translation: Little spruce, little spruce, kalado, kalado)

(Klētnieks 1968: 628)

In the 1930s, Petrula Buḷa appeared to be relatively easy to hire. In 1939, conductor of the Ludza Aizsargi (Home Guard) Division Choir and self-employed artist Pēteris Ore, collected folk songs from her. He also wrote the following:

"In Greči village in Nirza parish, I met 90-year-old singer Rozālija Bule. Her folk song repertoire is truly vast, but it can't be known if they can be sung in two melodies, because it was impossible to get more melodies from her. The song texts are completely Latvian, maintained within the verses and rhythm of the folk songs, likewise the motifs are sung in a completely unique way with a special accentuation. Not far from Rozālija Bule lives 67-year-old Petronela Buḷa. It turned out that 
she had already been invited to Rīga a few years ago to sing Estonian folk songs, because in her time she had been not only a great singer of Latvian folk songs, but also had known many Estonian folk songs. This time, however, I had no luck inspiring her to sing. The grey-haired lady had fallen upon hard times and she had lost the joy to sing. It is interesting to note that in Greči and Sčastlivije villages in Nirza parish there are still many Estonian families living now. The children of these families prefer to speak Latvian.” ("Vienā apriṇķ̄̄” 1939)

A few years after Pēteris Ore, the Soviet occupation came. In March 1941, Emilis Melngailis collected folklore materials for an art decade in Moscow ("Vāc folkloras materiālus" 1941). However, Petruḷa Buḷa's and the other "Nirza and Pilda parish Livonians' moment in the sun" in Moscow was apparently not meant to be.

\section{Latvian research expeditions in the 1970 s}

The 26th expedition of the Latvian SSR Academy of Sciences Andrejs Upīts' Language and Literature Institute Folklore Section took place in Summer 1972. Other participants included the employees of the Language and Literature Institute, the faculty of the Latvian Academy of Music, etc. The expedition focused on Ludza District ${ }^{18}$ and also interviewed Lutsis. A member of this expedition, Mirdza Berzinska documented the Lutsis' stories about their history and origins. Lutsi Marija Laizāne gave the following accounts: ${ }^{19}$

"Long ago, the Estonians of Ozupine village killed their manor lord at Janovole manor and were first to receive their freedom. The Latgalians envied the Estonians because of this, but nevertheless kept living under their manor lord's jurisdiction." (Berzinska 1972: 58)

"The Estonians attended a Latgalian wedding in Voiti village and joked to each other that the wedding meal would be 'kassi liha' - cat meat. All of the Estonians laughed, but because the Latgalians could not understand them, they thought that the Estonians just felt good at their feast and that was why they were so jolly.” (Berzinska 1972: 58)

18 Latvian: rajons.

19 "Marija Laizāne, 82 years old. She was born in Cibla parish in Ludza County. She went to school for one winter. Her mother was Estonian and spoke Estonian." (Berzinska 1972: 57) 
“The Estonians had sprightly girls, the Latgalians didn't, they were submissive, quiet.” (Berzinska 1972: 58)

"Sometimes their neighbours wondered how these Estonians came to be in Latgale, then the informant's (i.e., Marija Laizāne - author's note) father said: 'A black raven carried the Estonians from Estonia through the air. The Estonians fell out of the raven's pocket over Latgale, over Ozupine, Greči, Puncuḷi, and Abricki villages.”" (Berzinska 1972: 57)

The origin myth of the Lutsis given above is a somewhat analogous story to Fr. R. Kreutzwald's Kalevipoeg. Not only did the Lutsis fly, but also Kreutzwald's Kalev used flight in the Estonian national epic Kalevipoeg to reach his new home:

$\begin{array}{ll}\text { Kolmas istus kotka selga, } & \text { On an eagle sat the third one, } \\ \text { Põhjakotka tiiva peale... } & \text { On the northern eagle's wings. } \\ \text { See, kes sõitis kotka seljas, } & \text { He, who rolled away to Russia, } \\ \text { Põhjakotka tiiva pealla, } & \text { Rose to be a clever merchant, } \\ \text { Lendas palju, liugles palju, } & \text { Braider of the purls in shops. } \\ \text { Lendas tüki lõuna poole, } & \text { He, who blew to Tundraland, } \\ \text { Teise tüki tõusu poole, } & \text { Rose to be a valiant warrior, } \\ \text { Söitis üle Soome mere, } & \text { Wielder of the axe of warfare. } \\ \text { Liugles üle Läänemere, } & \text { He who rode the back of th'eagle, } \\ \text { Veeres üle Viru mere, } & \text { On the northern eagle's wings, } \\ \text { Kuni önne kohendusel, } & \text { Flew a long time, glided more, } \\ \text { Jumalikul juhatusel } & \text { Flew a distance to the south, } \\ \text { Kotkas kõrge kalju peale } & \text { Then another t'wards the sunrise, } \\ \text { Viskas mehe Viru randa. } & \text { Flew across the Finnish sea, } \\ \text { (Kreutzwald 1935: 16) } & \text { Skimmed across the Western sea, } \\ & \text { Rolled across the Viru sea. } \\ & \text { (Kreutzwald 2011: 31-32) }\end{array}$

Another member of the 1972 expedition Guna Pence, interviewed Lutsi informant Nikolajs Buḷ $\mathrm{s}^{20}$ son of Stanislavs, who told other stories of Lutsi origins:

"They say that the first Estonians came to live here when a manor lord had purchased them from Estonia in exchange for some goats." (Pence 1972: 124)

20 Research informant Nikolajs Buḷs son of Stanislavs. Born in 1911. He lived in Ludza District, Ozupiene village soviet (Latvian: ciema padome), Ščasțivi village. 
"There once was a law that Estonians could only marry each other. That is why everyone has the last name Buls here." (Pence 1972: 124) "The Estonians always kept together and apart from the Latgalians. They had their own parties. The Estonians couldn't stand the Latgalians and also vice versa. They also sat apart in church.” (Pence 1972: 124)

Irisa Priedīte, a researcher at the Ethnographic Open-Air Museum of Latvia, had the following to say about the museum's expedition in 1974 and its results:

"We turned our attention, even if only slightly, to the so-called Ludza Estonians. In 1974, 46 exhibits were brought from Pilda and Mērdzene parishes. These were made by individuals from Estonian or mixed Estonian-Latvian families. The archive contains descriptions of the lives, work, and traditions of 50 residents of these parishes (those who know their Estonian origins). A portion of these are supplemented with photographs." (Priedīte 1996)

Other aspects of the 1972 Lutsi expedition are described in the articles by Antons Breidaks (1932-2000) and Vija Jugāne. Breidaks provides a detailed overview of the unique features, the considerable multilingualism of the part of Latgale where Lutsi was spoken, and the importance of language contact in its development. He also gives some thought to the origins of the Lutsis and the presence and influence of Lutsi on local toponyms and family names.

"The study of different ethnic groups and language contacts elicits special interest in Latgale. This is because Russians, Belarusians, Poles, Estonians, and others have lived alongside Latvians (retrospectively, Latgalians) in this cultural historical region of Latvia since ancient times. The influence of the cultures and languages of the Slavic nations in Latgale has been extensively discussed in the scientific literature. Latvian and Lithuanian as well as Russian and Polish researchers have written about this question. Estonian and Finnish researchers have studied Estonian and Latgalian culture and language contacts. Latvian researchers have studied this issue relatively little." (Breidaks 1972a)

"Estonian SSR Academy of Sciences and Hungarian Academy of Sciences academic Prof. Paul Ariste has been especially interested in the Lutsis. He has been in Ludza District many times to collect Estonian dialect materials. P. Ariste has broadly examined the features of the Lutsi dialect, which reflect influence from Latvian, Russian, Belarusian, 
and Polish. In his article 'Examples of language contact in Latgale', P. Ariste recognises Ludza District as one of the most interesting regions in the Baltic, because it is possible to observe the processes and results of contact among languages of various origins. He thinks that some Estonians settled in Ludza District long ago, but the majority in the 17th century. There are many names of settlements in Ludza District, which were borrowed from Estonian, for example, Germi, Kaupuzy, Lynužy, Paidery, Pylda, Raibakozy, Spenery. The influence of Estonian can also be seen in many exterior place names, which are borrowed from Estonian, for example, Ašu plova, Boku mežs, etc. Nowadays only rarely do older Estonians still remember the ancient exterior names, which they once used in their full form, for example, in Cjapši village there is a meadow named Havesta kolk, hills named Kaudu megi, Lavaamegi, Sanaavarik, etc. There are also a few last names of Estonian origin in Ludza District, for example, Kaupužs, Poikāns, Soikāns, Unda, Zeps, etc. These examples testify to the extensive influence of Estonian on the Latgalian subdialects of Ludza District.” (Breidaks 1972b)

The 1972 expedition still encountered the last people who had grown up and lived their lives with Lutsi, even if by then they may not have spoken it very often anymore. In her article, Vija Jugāne describes her conversation with Antonina Nikonova (1898-1983), whose grandson Nikolajs Nikonovs (1944-2006) would be the last speaker of Lutsi, and shows Nikonova's attitudes towards her unique knowledge and language in a world where very few others can understand it.

"Estonian Antonina Nikonova of Pilda village sang her folk songs. She said she would sing three, but sang two. When she returned to her place, we asked why she didn't sing the third one. 'Well, why should I sing it, you won't understand what I'm singing about anyway. It could be that I'm making fun of you,' she smiled back at us. This grandmother's words describe in a practical way the attitude of a singer in Latgale towards song - the text and melody are a single whole /.../ because by singing to an audience it is possible to describe the events about which the song is written with more feeling." (Jugāne 1972)

The observations and conclusions of the expedition members found in Jugāne's article help, in some measure, to get a sense of the shared and separate - of Latgale and the Lutsis. They also show the differing attitudes of younger and the very youngest generation towards this vanishing heritage. 
Figure 3. Lutsi speaker and singer Antonina Nikonova in Lielie Tjapši village. (Source: Pence 1972: 6).

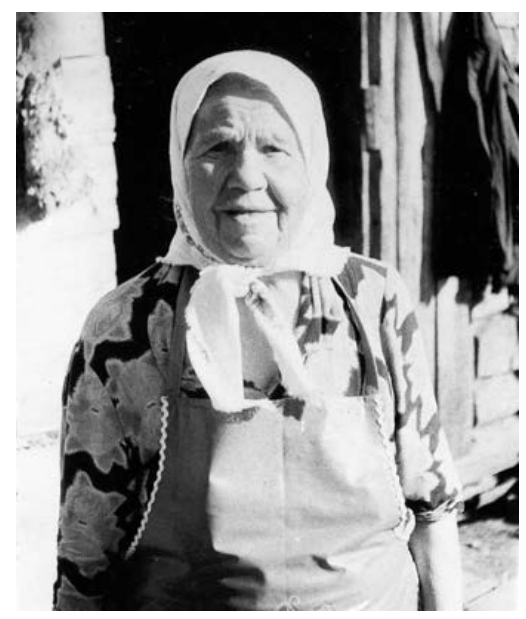

"In the past there were several Estonian villages here and their residents separated themselves from the Latgalians, they tried to maintain their culture. Now, of course, everyone is cooperating, in daily life it's not possible to say who is Latvian, who is Estonian. It turns out that there are still fifteen Estonians of whom four speak Estonian fluently. The oldest of them - Jezups Jakimenko - is 96 years old /.../ So, at the last moment it was still possible to collect materials of immeasurable value to study the mutual influence of two language groups, two cultures, and how they develop.

/.../ in this expedition there was an occasion where educated children were ashamed of their own ethnic culture /.../ Researcher Mirdza Berzinska elaborates: ${ }^{21}$ 'I have had occasion to observe how small children listen to songs and stories with the greatest of interest, while young people seem to be ashamed of these or are only interested in the stage. The old women complain: no one knows how to sing at weddings anymore, they just warble; I don't know how to do that and don't want to. I asked the [language and culture] informant Antonina A. if her children also sing. - One daughter does have a good voice, but she only sings those modern songs, she doesn't like the old ones. And it also doesn't turn out well. If she tries. I don't know if it's the fault of her voice or /.../ Maybe she doesn't feel the song's soul /.../ Nowadays young people don't know how to have fun without drinking, and the song doesn't sound right. And when they get drunk, it doesn't sound right either.

21 An employee at the Archives of Latvian Folklore (Latviešu folkloras krātuve) and collector of folklore for many years; a contributor to the publication Latviešu tautasdziesmas (Latvian folk songs). 
And they don't remember the words or the melody. Children, however, according to the observations of every expedition member, listen in rapt attention to the songs, stories, and legends told by their grandmother and grandfather. Even in the scientific session, which lasted for several hours, the small girls and boys sat unblinking and listened with great interest not only to the performances, but also to the speeches. Probably by respecting their people's folklore in their childhood, they will also respect their people's creative works, by continuing to pass down their folklore across the generations." (Jugāne 1972)

The Lutsis were suddenly mentioned again at the folklore festival "Baltica-89":

"The noteworthy Estonian folklorist Oskar Kallas studied the ethnography and folklore of the Lutsis. As the residents of Rogovka village knew, there was still a woman alive in 1975 who knew Estonian folk songs. In this sense, Ludza District, which is also where Rogovka village is located, has been a kind of micromodel of the cultural situation characteristic of the Baltic. The Latvian and Estonian, or more broadly speaking - Baltic and Finno-Ugric, cultures interacted and influenced each other in this place." (Kiope 1989)

\section{Conclusion}

The Lutsis are currently experiencing a revival in Latvia among descendants while also being (re)discovered among the wider population of Latvia and the Baltic States. However, the Lutsis have been the focus of research and articles in the popular media since the middle of the 19th century. This article traced the Lutsi presence in the press and in the notes of researchers over this time up to the 1970s when the last generation of those who had grown up speaking Lutsi and lived with Lutsi were still alive providing a unique insight into not only the language and culture contact that has characterised the Lutsi community over its existence, but also the attitudes of Lutsis and their descendants towards the state of that language and culture at that time. 


\section{References}

Balodis, Uldis. 2020. Lutsi kiele lementar. Ludzas igaunu valodas ābece. Rīga \& Ludza: LU Lībiešu institūts, Ludzas pilsētas galvenā bibliotēka.

Berzinska, Mirdza. 1972. ZA Valodas un literatūras institūta folkloristu 26. zinātniskās ekspedīcijas dalībnieces M. Berzinskas savāktie materiāli Ludzas rajonā. 1972. gadā. (LFK [2005] 1418-1663). Unpublished field notes.

Blese, Ernests. 1925. Latgales cittautieši un viṇu valodas. Izglītības ministrijas mēnešraksts 4. 357-358.

Breidaks, Antons. 1972a. Par Baltijas somu un latgaḷu etniskajiem sakariem. Dzimtenes Balss, August 24.

Breidaks, Antons. 1972b. Par Baltijas somu un latgaḷu etniskajiem sakariem. Dzimtenes Balss, August 31.

"Galvas pilsētā". 1932. Latvijas Kareivis, June 19.

Jääts, Indrek. 2013. "Eestirahwa unustatud suguharu”: Lutsi maarahva retseptsioon Eestis 19. sajandi lõpust II maailmasõjani. Manuscript. Tartu: Eesti Rahva Muuseum.

Jääts, Indrek. 2014. Üks kuulus välitöö ja selle pikk vari: Oskar Kallas, Paulopriit Voolaine ja Lutsi maarahvas. Eesti Rahva Muuseumi aastaraamat 57. 14-41.

Jēkabsons, Ēriks. 2013. Lietuviešu tautības priesteri Latvijā 19. gadsimta beigās 1940 gadā. Katoḷu 2014 kalendārs - Katoḷ Baznīcas Vēstnesis 2013. 109-110.

Jugāne, Vija. 1972. Pa baltajiem Latgales ceḷiem. Padomju jaunatne, August 13.

Kallas, Oskar. 1894. Lutsi maarahvas. Helsinki: Suomalaisen Kirjallisuuden Seuran Kirjapaino.

Kallas, Oskar. 1900. Achtzig Märchen der Ljutziner Esten. Tartu: Schnakenburg’i trükikoda.

Kemps, Francis. 1910. Latgalieši. http://lakuga.lv/2011/12/24/kemps-latgaliesi/ (6 March 2021).

Kiope, Māra. 1989. Laula, kuni elad! - Dziedi, kamēr dz̄ivo!. Padomju jaunatne, July 21.

Klētnieks, V. 1968. Kaladū vārda cilme. Labietis 36. 628.

Korjuss, Hanness. 2017. Ludzas igauñi. Zemes dieva tauta. Rīga: Izdevniecība "Lauku avīze".

Kreutzwald, Friedrich Reinhold. 1935. Kalevipoeg. Tartu: Eesti Kirjanduse Selts.

Kreutzwald, Friedrich Reinhold. 2011. Kalevipoeg: The Estonian national epic. Translated by Triinu Kartus. Tartu: Eesti Kirjandusmuuseum; Tallinn: Kunst.

Kursīte, Janīna. 2008. Latgaliskais latviskums. Diena, February 19. https://www.diena.lv/raksts/kd/zinas/latgaliskais-latviskums-37395 (6 March 2021).

“Kur Latgale beidzas Ceḷojuma pēczīmes”. 1911. Zemkopis 30, July 27. 586-588.

Ludzeneeks, M. 1932. Pahrtautoschana Ludzas apriṇkī. Pehdejā Brihdī, July 8.

"Lutsi eestlased vajavad õpetajaid". 1930. Postimees, December 14.

““Maajumala poig Filip Mihhailovits'. Dr. O. Kallas Lutsi maarahva apostlina”. 1943. Järva Teataja, October 28.

Manteifels, Gustavs / Manteuffel, Gustaw. 2020. Poḷ Inflantija. Inflanty Polskie. Rīga: Jumava. 
Melngailis, Emilis. 1934. Ko ceḷagajejs cieš. Mūzikas apskats 4. 112.

Melngailis, Emilis. 1938. Aiz devini dziesmusvētki. Atpūta 711. 24.

"No Ilzenes". 1911. Latviešu Avizzes, June 14.

Ozols, J. 1932. Par Ludzas apriṇķa pamatskolu stāvokli un darbību 1930/31 mācības gadā. Latgales ziñas, July 1.

Pence, Guna. 1972. ZA Valodas un literatūras institūta folkloristu 26. zinātniskās ekspedīcijas dalībnieces G. Pences savāktie materiāli Ludzas rajonā. 1972. gadā. (LFK [2005] 985-1271). Unpublished field notes.

“Pilda (Vitebskas gub.)". 1911. Dzimtenes Vèstnesis, June 1.

Priedīte, Irisa. 1996. Latvijas rietumsomu materiālās kultūras liecības. Latvijas Vēstnesis, July 4.

Sementovskij, Aleksandr. 1872. Etnografičeskij obzor Vitebskoj gubernii. St. Petersburg: Tipografija M. Xana.

Štšerbinskis, Valters. 2007. Läti eestlased ja Riia poliitika kahe maailmasõja vahel. In Leili Utno (ed.), Eestlased Lätis I. Tallinn: Kirjastus "Välis-Eesti”. 137-149.

“Tautību stāvoklis Latgalē”. 1913. Dzimtenes vēstnesis, April 10.

"Vāc folkloras materiālus mākslas dekadai Maskavā". 1941. Cīnna, March 9.

"Vienā apriṇḳī savāktas 350 tautas dziesmu melodijas". 1939. Daugavas Vēstnesis, August 30.

Voolaine, Paulopriit. 1921. Külaskäik Lutsi maarahva juures. Postimees 178, August 10. Voolaine, Paulopriit. 1926. Lutsi maarahva eestilisest liikumisest. Üliõpilasleht 3. $37-40$.

Voolaine, Paulopriit. 1932. Läti surve vähemusrahvustele. Mis saab uue suuna juures eestlaste koolidest? Postimees, February 24.

Voolaine, Paulopriit. 1963. Paulopriit Voolaine tegevus eesti keele alal. EKLA, F 169M 197: 2.

Kokkuvõte. Hannes Korjus: Sementovskijst 20. sajandisse. Märkmeid lutsidest Läti ajakirjanduses. Kunagine lõunaeestikeelne lutside kogukond elas Kagu-Lätis Ludza linna ümbruses. Lätis on nad saanud suurema avaliku tähelepanu osalisteks alles viimastel kümnenditel, kui on ilmunud raamatuid nende ajaloo ja keele kohta nii asjatundjatele kui ka laiemale huvirühmale ning on hakatud elavdama lutsi rahvakultuuri. Siiski ka enne seda viimast aktiivsuse tõusu on lutsidest kirjutatud Läti ja Eesti ajakirjanduses ja on ilmunud välitööde märkmeid lutsidega seotud uurimuste tegijatelt. Antud artikkel jälgib lutside kirjeldusi erinevates allikates alates varastest mainimistest 19. sajandi keskel, jätkates maailmasõdadevahelise perioodiga ning jõudes viimaks 1970. aastateni, kui Läti uurijad dokumenteerisid oma ekspeditsioonidel viimaste lutsi kõnelejate keelelist ja kultuurilist olukorda.

Märksõnad: etniline identiteet, ohustatud keeled, vähemuskeeled, läänemeresoome keeled, lõunaeesti, Lutsi, Latgale, Ludza 